November 2016

\title{
Could Technology End Secrecy?
}

Chris Hables Gray

University of California, Santa Cruz

Follow this and additional works at: https://scholarworks.sjsu.edu/secrecyandsociety

Part of the Arts and Humanities Commons, and the Social and Behavioral Sciences Commons

\section{Recommended Citation}

Hables Gray, Chris. 2016. "Could Technology End Secrecy?." Secrecy and Society 1(1). https://doi.org/10.31979/2377-6188.2016.010106 https://scholarworks.sjsu.edu/ secrecyandsociety/vol1/iss1/6

This Article is brought to you for free and open access by the School of Information at SJSU ScholarWorks. It has been accepted for inclusion in Secrecy and Society by an authorized administrator of SJSU ScholarWorks. For more information, please contact scholarworks@sjsu.edu. 


\section{Could Technology End Secrecy?}

Keywords

media ecology, privacy, secrecy, surveillance, technology, veillance

This article is available in Secrecy and Society: https://scholarworks.sjsu.edu/secrecyandsociety/vol1/ 


\section{Could Technology End Secrecy?}

\section{Chris Hables Gray}

Secrets are lies...when there's something kept secret, two things happen. One is that it makes crimes possible. We behave worse than when we're not accountable. That goes without saying. And second, secrets inspire speculation. When we don't know what's being hidden, we guess, we make up answers. - Mae Holland ${ }^{1}$

In the 2013 novel, The Circle, a social media corporation subsumes Facebook, Twitter, Google, Pinterest, Instagram and the rest of the big players in digital community and creates one unified on-line system where anonymity is impossible, thanks to its incredibly effective TruYou app. The main character, Mae Holland, goes from being a newest "Circler" to its most fanatical employee. She coins their triple-headed mantra: "Secrets are Lies. Sharing is Caring. Privacy is Theft." The "sharing" by the way, is not of the incredible wealth the Circlers enjoy, but rather of information--personal information. Under these principles, and thanks to its incredible efficiencies, The Circle spreads its cheap networked SeeChange mini cameras around the world and the corporation also becomes the single portal for all governmental functions (voting to emergency aid), all digitized personal networking, most business transactions, and the force behind the fad of going transparent, opening one's whole life to the gaze of the rest of

1 From Eggers (2013, 297). 
humanity and our machines. Margaret Atwood, in her laudatory review of The Circle (2013), comments the two "serious" purposes of the book:

One of them is to remind us that we can be led down the primrose path much more blindly by our good intentions than by our bad ones...A second may be to examine the nature of looking and being looked at.

For it is good intentions that create this digitalized Brave New World. Total transparency seems to promise an end to loneliness and crime, incredible increases in all sorts of efficiencies, and even a radical improvement in democracy through direct voting on everything from vegan options for lunch to drone assassinations. The Circlers call it "Demoxie" -"It's democracy with your voice and your moxie" (Eggers 396). This is John Keane's important idea of Mediated Democracy on steroids, but with a small elite (the corporate leadership of The Circle in this case) in total control of the flow of information, for the good of all, of course.

And it is a new way of looking, mediated by digital technology, that makes this sea change in the meanings of the gaze possible. Taken altogether with the new technologies, this vision of transparency is a radical reframing of what privacy and secrecy can mean to society, taking us back to the days of the small band or village, where everyone knew almost everything everyone did, from bad digestion to successful sex. Except now, with technology, we can all know more about everyone else.

For some people this is so clearly Hell they cannot take the book seriously but they underestimate its appeal. Eggers certainly is not in favor 
of this digitized panopticon, but he is right about its attractions, and not just to insecure Silicon Valley "bliss ninnies" but also to thoughtful, hard bitten (indeed cynical) science fiction writers as well.

In his 1990 novel, Earth, David Brin describes a near future where a world wide revolutionary movement has abolished privacy. Their argument is that regular people had long lost their privacy to a surveillance (observation from above) regime of governmental spying, corporate market research, and the interweb of things, so many of them watching, listening, monitoring. It was only the rich who still had privacy, and they were using it to steal and cheat and basically fuck over everyone else. The revolutionaries, mainly from looted countries, wage a successful war on Switzerland to get back their stolen wealth squirreled away in the Alps.

This leads to a society where every moment of every person is accessible to viewing, just as with those who have gone "transparent' in The Circle. Of course, most of the time the average person isn't being observed by humans, but they could be. They are always being recorded. And finally, the rich and powerful (and the famous and notorious) are under constant sousveillance (observation from below, pronounced without the second " $s$ " as in "sou" veillance). The book has other themes, ecological disaster, AI's run amok, the typical SciFi/CliFi mix. But Brin's take on the oppressive nature of privacy hit a nerve and he ended up defending it in a Wired 
Magazine article and then a nonfiction book, The Transparent Society: Will Technology Make Us Choose Between Freedom and Privacy?

Brin is obviously being provocative, as Eggers is in his own way. But their insight is real. Digital technology is fundamentally changing the very way we think about secrecy and privacy. The first impacts of this have been mixed. For example, digital harassment, trolling, and bullying have become problems but the widespread sousveillance of police actions has fueled the growing movement for police accountability, including the important Black Lives Matter! campaign. Steve Mann (2013), famous for his work on wearable computing, coined this term term sousveillance, and argues that driven by constantly expanding digital technologies we are creating a Veillance Society that includes not just "sou" and "sur", but "self/auto/soi" (Fitbit, etc.) and "peer/pair" veillances as well.

In some key ways, the Veillance Society started with the massive collection of Big Data, including secrets, by governments, which allowed the massive revelation of secrets through Wikileaks, Manning, Snowden, and Snowden2 (the unknown post-Snowden leaker of NSA secrets).

Governmental and individual privacy and secrecy are now major political issues that are far from settled. But already it is becoming obvious that corporations are as hungry for "private" information as governments, and often there is even less accountability, although whistleblowers are clearly crucial, as the recent Mossack Fonesca law firm leaks show. 
But no matter what happens with digital information, at least we will always have our private thoughts deep and secret in our minds? There we can think whatever we want and no one can know. Right? No. Or at least, not for long. Just as digital technoscience is growing a veillance society right before our eyes, sucking up secrecy, it is also creating the technologies to read, and thus inevitably control, human minds. Long a dream of scientists (and politicians), direct mind control has now become feasible thanks to a powerful new technoscience, optogentetics, made possible only through the sophisticated knowledge heavily mobilized Big Data can provide.

Optogenetics is genetic engineering chimeras, creatures with DNA from two species, so that the neurological tissue of the subject can be effectively manipulated using light. Many organisms have developed photosensitive tissues (our eyes, jellyfish, bacteria, fungi). DNA from photosensitive organisms are "infected" into neurological tissue so that the neurons can be "turned on or off" with photons. Experiments are taking place with insects, reptiles, rodents, and primates (Gorman 2014).

Optogenetics offers tremendous potential for treating a wide range of neurologica disorders and, eventually, augmenting human cognitive capabilities incredibly. And also there's the mind reading/mind controlling applications. Yes, it sounds like science fiction, but so much does these days. Optogenetics (and its cousin sonogenetics using sound sensitive neural tissue) already has made it possible to implant memories in the 
dreams of rats and monkeys, to make it possible to turn on and off memories with the flick of a switch, to control a body like a meat puppet, and to record and read specific thoughts. Its potential is extraordinary (Gray 2014). And when you consider that lie detector systems that utilize real time three dimensional brain imaging to determine previous recognition are already acceptable in court, it is clear that your private thoughts may someday be no more secret than your email is today.

So can technology end secrecy? Yes. This is just the beginning. The future of secrecy is being shaped by the scientific discoveries and technological creations of today, and by the politics and understandings that contextualize them. Now, more than ever, we need thoughtful, engaged, and committed scholarship to help shape this future into one that isn't a nightmare, no matter how well intentioned, no matter how seductive.

\section{References}

Atwood, Margaret. 2013. "When Privacy Is Theft." The New York Review of Books November 21. Accessed June 8, 2016. http://www.nybooks.com/articles/2013/11/21/eggers-circle-whenprivacy-is-theft/

Brin, David. 1990. Earth. New York: Bantam Spectra. . 1998. The Transparent Society: Will Technology Make Us Choose Between Privacy and Freedom? Reading, MA: Perseus Books. 
Eggers, Dave. 2013. The Circle. New York: Alfred A. Knopf.

Gray, Chris Hables. 2014. "Big Data, Actionable Information, Scientific Knowledge and the Goal of Control." TeknoKultura 11 (3): 529-54. http://teknokultura.net/index.php/tk/article/view/239/pdf_1

Keane, John. 2009. The Life and Death of Democracy. New York: Simon \& Schuster.

Mann, Steve. 2014. "Maktivism: Authentic Making for Technology in the Service of Humanity," In "DIY Citizenship, Critical Making and Social Media," edited by Matt Ratto and Megan Boler, 1-24. Cambridge, MA: MIT Press. Accessed June 8, 2016. http://www.eyetap.org/papers/docs/DIY_Citizenship_book_chapter1_St eveMann.pdf 